\title{
PRELIMINARY STUDIES OF FUEL BRIQUETTES FROM WOOD WASTE
}

\author{
Jacek Caban $^{1}$, Jozef Jandacka ${ }^{2}$, Aleksander Nieoczym ${ }^{1}$, Michal Holubcik ${ }^{2}$, Jan Vrabel ${ }^{2}$ \\ ${ }^{1}$ Lublin University of Technology, Poland; ${ }^{2}$ University of Zilina, Slovakia \\ j.caban@pollub.pl, jozef.jandacka@fstroj.uniza.sk, a.nieoczym@pollub.pl, \\ michal.holubcik@fstroj.uniza.sk, jan.vrabel@fpedas.uniza.sk
}

\begin{abstract}
The necessity of using renewable energy sources and limiting the current consumption of fossil fuels was emphasized, among others by changes in production technology. The approach of sustainable development in current energy systems is extremely important, especially in the case of plant-based fuels (biofuels). Poland is a country, where the share of renewable energy sources is still relatively small, and there are ongoing discussions on abandoning coal-based energy and the final shape of energy policy. In addition, the use of biomass from agricultural areas is not too large, although there is a potential for them in the sustainable biomass production plant and this would enable the development of the underdeveloped regions of the country. The most commonly used solid biofuel are briquettes made of vegetable waste, which, with the appropriate production technology, allow to obtain heat with a combustion value similar to that of hard coal. The article presents the preliminary results of laboratory tests of physical properties of fuel briquettes made of wood waste. The research was carried out on three types of wood shavings: pine, oak and hornbeam measuring their density depending on the type of wood and the size of the chip fraction in the pressing process. It has been shown that the size of the raw material fraction has an influence on the obtained density of fuel briquettes. The aim of the research was to determine the suitability of the studied waste wood materials for energy purposes for the production of briquettes. Attention was drawn to the fact that biomass for energy purposes is one of the steps to sustainable energy production and reduction of fossil fuel yield.
\end{abstract}

Keywords: biomass, briquette, energy, chips.

\section{Introduction}

In 2012, the document "The future we want" was created at the conference "Rio +20 " in Rio de Janeiro, containing the framework of planned Sustainable Development Goals. It provided the basis for the document "Transforming our world: Agenda for Sustainable Development - 2030" adopted on 2527 September 2015 at the UN forum. It contains 17 Sustainable Development Goals included in five groups [1]. In the group called "Raw Materials Triad" the topic: "Climate, Energy" was highlighted due to increasing energy needs and depletion of fossil fuels, which are the main reason for global climate change. The goals of "Sustainable Development" adopted by the United Nations resulted from the efforts of the EU countries to reduce $\mathrm{CO}_{2}$ and reduce the greenhouse effect. The EU countries were the first to adopt legislation convergent with a UN resolution aimed at protecting the environment and reducing fossil fuel extraction. Stimulating the development of renewable energy sources (RES) is conducive to supporting the implementation of the idea of sustainable development. The development of renewed sources is one of the guarantees of energy security [2;3], increase in energy efficiency and market competitiveness. The integration of these activities also contributes to improving the quality of life of local communities and reduced pressure on the natural environment. Every one of us can quite easily reflect over his/her energy use behaviour - related to transportation, direct household energy use and indirect energy footprints related to consumption of food and other material goods [4]. It has been accepted by several researchers that the socio-economic and socio-demographic factors influence societal energy use to a great extent, and while understanding the links is a complex task, implementing interventions to bring about change is even more challenging [5-7]. Sustainable energy development in the context of the renewable energy market can be realized when all activities are integrated at the local, national and global levels and at various levels of this development: economic, social, psychological, environmental, technological, political, legal and information. The development of alternative energy sources is particularly noticeable in the transport sector [8-14], where more environmentally friendly fuels are sought in terms of gas emissions from combustion processes in internal combustion engines. In work [15] they examined the possibilities of improving the ecological parameters of an internal combustion engine.

In recent years, the growing demand for biomass was the result of the introduction of the Directive 2009/28/EC of the European Parliament and of the Council on the promotion of electricity generated from renewable energy sources. In future energy scenarios, biomass will play an important role in the energy supply [16]. For Polish energy policy, the basic document is "Poland's Energy Policy until 
2030", adopted by the Council of Ministers on January 4, 2010. The use of renewable energy sources, including biofuels, is one of six priority directions in Poland's energy policy. In this area, the document formulates three basic objectives:

- an increase in the use of renewable energy in final energy consumption to $15 \%$ in 2020 and a further increase in this indicator in subsequent years;

- achieving a 10\% share of biofuels in the transport fuel market in 2020 and maintaining this level in the following years;

- protecting forests against excessive exploitation for the purpose of obtaining biomass and the sustainable use of agricultural areas for renewable energy, including biofuels, so as to avoid competition between renewable energy and agriculture.

This article presents the preliminary results of laboratory tests on the physical properties of briquettes from wood waste. For three types of wood shavings: pine, oak and hornbeam, with different fraction sizes, density measurements were made depending on selected variable pressing parameters. The main objective of the research was to determine the suitability of wood chips for energy purposes in the briquetting process due to their density.

The use of agricultural biomass can significantly contribute to stimulating economic development in rural areas through diversification of activities (new markets for agricultural raw materials, new types of economic activity) and should constitute an important element of agricultural policy [17]. It is assumed that the biomass obtained for this purpose will largely come from energy crops. Agricultural residues represent a cheaper energy source than wood, but their use has some technical limitations [1820]. In addition to biomass from agricultural, importance is attributed to the use of forest biomass and biomass contained in various types of industrial and municipal waste [21-24]. For example, Norway has abundant forest resources and more than $40 \%$ of the land is covered by forests [25]. Biomass materials from the forest have a great potential to provide suitable feed stocks for bioenergy [25]. One of the ecologically safe methods of waste management is the use of their combustible fractions as fuels in hightemperature combustion processes [26]. The chemical composition and physical characteristics of individual types of biomass may differ significantly [27-29]. The chemical composition of biomass depends on the physiological characteristics of plant species, as well as the development phase, plant organ, variety, fertilization and chemical protection, soil richness in nutrients, date and manner of harvesting, as well as transport and storage [30; 31]. Knowledge of the characteristics of plant raw materials is of great importance from the energy point of view, because each parameter has an impact on the course and efficiency of biomass burning [29; 32-34]. Therefore, biomass is a flexible energy source that can be converted into various energy products to meet different demands [30]. Replacement of fossil fuel with renewables including biomass is one of the ways to ensure sustainable development $[35 ; 36]$.

Renewable energy sources can help in the fight against climate change, but knowledge about their impact on soil, air and water is also needed. The so-called method of carbon footprint is used in two energy scenarios. The "100\% scenario" assumes a total shift towards bioenergy, mainly in the form of bioelectricity and first-generation biofuels. The "SDS-bio scenario" is based on the documents of the International Energy Agency (IEA) and assumes a 9.8\% share of bioenergy in total world energy production. The results of the analysis indicate that the " $100 \%$ scenario" of the transition to bioenergy is not possible from the perspective of the use of water and land resources. The "SDS-bio scenario", when using the most efficient raw materials (sugar beet and sugar cane), would require the use of 11$14 \%$ of global arable land and water resources, and would reduce $\mathrm{CO}_{2}$ emissions and obtain $18-25 \%$ of the current carbon footprint.

There are three main activities necessary to produce moulded solid fuel: drying, comminution and moulding [37]. The diverse composition of plant briquettes requires testing of their physical, mechanical, and chemical properties. In most cases, specially manufactured laboratory briquetting presses are used for testing. Examples of such constructions are devices presented in scientific works by Kriżan [38] and Soos et al. [39]. The results of tests of physical properties and calorific values are the basis for creating standards dedicated to briquettes with a specific raw material composition $[32 ; 38$ 43]. 
The process of producing briquettes is carried out by means of screw or piston presses and is associated with a change in pressure in the pressing chamber. The changes in briquette density depending on the pressure in the working chamber are significantly affected by the diversity of the physical and mechanical properties of wood chips, in particular the geometrical dimensions of the raw material particles [38]. The RUF type briquettes are produced on a hydraulic press, in which the pressed raw material is subjected to a pressure of 300 to 400 bar. Cylindrical briquettes are produced on hydraulic or mechanical impact presses, in which it is possible to obtain a compression pressure of 400600 bar. The highest compression pressures of the charge material occur during the production of Pini Kay briquettes on screw presses and amount to 1000-1100 bar. By using a combination of very high pressure and heat treatment, a product with high resistance to mechanical damage, high moisture resistance, high calorific value and long burning time is obtained.

During the production of wood briquettes, ecological supplements (no more than $2 \%$ ) can be used. The most frequently added supplement is lignin obtained from craft black liquor by precipitation in acid medium. In [44] the results of studies on the relationship between the percentage of lignin in the process of producing briquettes in order to increase their density and mechanical strength are presented. In the production of briquettes, an important parameter affecting the briquette density is the humidity of the input material. If the moisture content exceeds $14 \%$, the briquette breaks into pieces [44]. The calorific value of wood briquettes is within $4.5 \div 5.0 \mathrm{~kW} \cdot \mathrm{h} \cdot \mathrm{kg}^{-1}$. Such a high calorific value of the briquette is obtained, on the one hand, due to the high density after pressing, on the other - due to the low final humidity (usually less than 10\%). Briquettes made of coniferous sawdust, thanks to the content of flour meal, in the combustion process quickly reach maximum temperature. The briquette made of $100 \%$ bark does not burn, but it smoulders giving heat, lasting up to $10 \div 12$ hours [45].

The heat of combustion of biomass therefore depends mainly on the percentage of cellulose, hemicellulose, and lignin in its structure. The highest heat of combustion is characterized by extraction compounds containing large amounts of resins and terpenes, however, their low content in biomass, not exceeding $9.5 \%$, causes only a small increase in the heat of combustion. High-calorie compounds (resins, terpenes, waxes) in the highest concentration are found in coniferous wood, which causes that the heat of combustion of these materials is higher compared to deciduous wood or herbal biomass [46]. The factor determining the high value of the heat of combustion is therefore the proportion of lignin in relation to holocellulose. Dry (hardwood) wood contains $43-50 \%$ cellulose, 20-25\% hemicellulose and 16-25\% lignin, while dry (softwood) wood contains 35-44\% cellulose, 25-30\% hemicellulose and 27$33 \%$ lignin [46].

When burning briquettes from wood waste, a low ash content $(0.5 \div 1.0 \%)$ is obtained. The emission of carbon monoxide to the atmosphere during the combustion of fuel briquettes is minimal, the smoke is colourless, transparent. The emission of soot, ash and other solid particles during briquette combustion is practically zero. Despite these advantages, research is underway to determine the standards for particulate emissions below $2.5 \mu \mathrm{m}$ [47]. However, the ash content does not depend on the burning process, but on the source of the biofuel.

\section{Materials and methods}

Three groups of samples: pine, oak and hornbeam (Tab. 1), 9 replicates each were compared in the study in order to verify the differences between them depending on the fraction size used.

\section{Content of structural components in various types of biomass, data in relation to the dry state $[48]$}

\begin{tabular}{|c|c|c|c|}
\hline Type & Lignin & Cellulose & Extractives \\
\hline Pedunculated oak & 24.67 & 46 & - \\
\hline Pine & $18-26$ & $37-45$ & 8.81 \\
\hline Hornbeam & 22 & 43 & - \\
\hline
\end{tabular}

During the tests, the density of fuel briquettes samples was determined depending on the size of the raw material fraction, type of wood, pressure value and speed of the compression cylinder piston. The shavings used for the tests were created as a result of milling and planning boards of pine, beech and oak [43]. Boards are made of wood after 6 months seasoning and then dried in the dryer. The moisture 
content of the boards was measured using a drying and weighing method and was $12 \%$. Various wood shavings did not mix with each other. Chips obtained from industrial boards provide stabilized wood material. Therefore, all analyses regarding the age of the wood, its thickness or the place where the wood sample came from, are omitted [43].

Chipped chips with 5, 10 and $15 \mathrm{~mm}$ lengths were used for the tests. The tested samples had a diameter of $40 \mathrm{~mm}$ and a thickness of $50 \mathrm{~mm}$. The chip size results from the recommended values

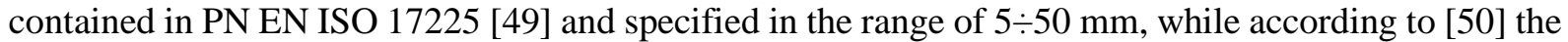
chip size should be in the range of $6 \div 15 \mathrm{~mm}$. This is due to the fact that larger ones create the structure of the briquette and generate formation of shaped connections, increasing strength. This is especially important in the case of briquettes produced at a low process temperature, which weakly activates strong joints at the contact points (plasticization of lignin and other binders). The chips were separated into fractions according to PN-EN ISO 17827-1 [51] and PN-EN ISO 17827-2 [52]. A set consisting of 63 mesh sieves was used $63 ; 45 ; 31.5 ; 15 ; 8 ; 5 ; 3.15 ; 2.5 \mathrm{~mm}$.

The crushed material was subjected to drying in a SLW 115 laboratory dryer from Pol-Eko until the moisture was completely removed. The drying process was carried out at $80^{\circ} \mathrm{C}$. This level of drying temperature was adopted, as it allows slow removal of water from biomass, and at the same time prevents the release of other volatile components that can have a positive effect on the thickening process. Drying was considered completed, when no changes were noted between the subsequent mass measurements. Weight measurement was carried out at 2-hour intervals on a RADWAG WLC10/A2 balance. After drying and milling, the material was stored in hermetically sealed containers. The diameter and height of the briquettes were measured using a calliper with a display resolution of $0.01 \mathrm{~mm}$ and their mass was determined on a RADWAG WLC10/A2 laboratory balance with an accuracy of $0.1 \mathrm{~g}$. The material after the drying and milling stage was stored in hermetically sealed containers.

The construction of a hydraulic testing device is shown below. It was made to determine the properties of wood chip briquettes depending on the parameters of the working process. Research results are also aimed at determining the direction of development of equipment for the production of briquettes. Fig. 1 shows a scheme of the stand for testing the physical and mechanical properties of raw materials for production of fuel briquettes. The stand consists of two main systems: work and registering. The working system consists of: electric motor coupled with the main hydraulic pump $(1,2)$, safety valve (3), limiting the maximum pressure. The actuator is a double-acting cylinder (6), hydraulic valve (4), an adjustable choke (5).

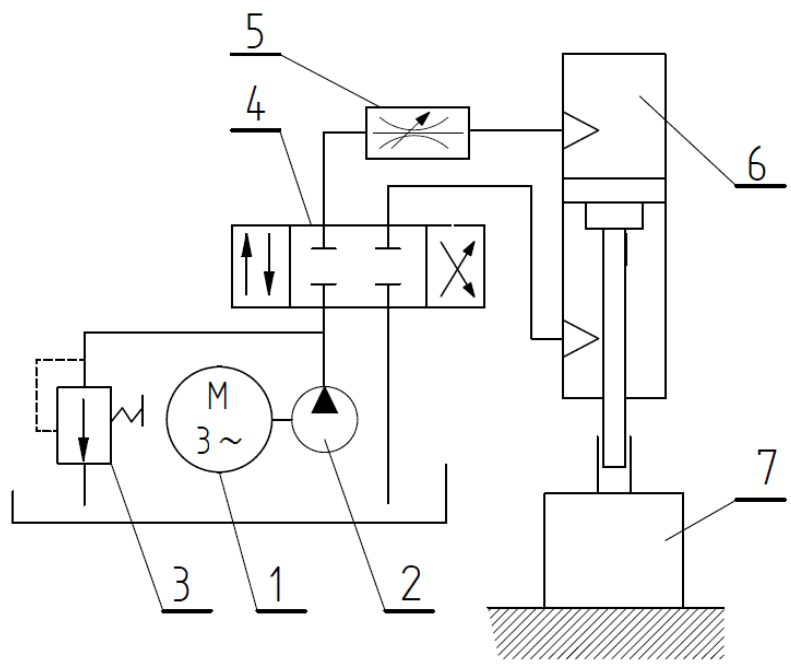

Fig. 1. Scheme of the test stand: 1 - electric drive motor; 2-main hydraulic pomp; 3 - safety valve; 4 - hydraulic valve; 5 - adjustable choke; 6 - double-acting cylinder; 7 - working chamber

The measuring system is equipped with extensometric pressure sensors with a measuring range of $0.5 \div 20 \mathrm{MPa}$ and an accuracy of $\pm 2 \%$. The test stand is equipped with the following elements for receiving, processing, and transmitting signals: multi-channel ADC converter with channel multiplexing, 2-channel digital to analog converter (DAC), amplifier with individual gain factor. It is possible to receive and process up to eight analog signals in the frequency range from 0 to $350 \mathrm{kHz}$. The 
construction of the station uses a $5 \mathrm{~kW}$ hydraulic pump that can generate a pressure of $21.0 \mathrm{MPa}$ and a flow of $40 \mathrm{l} \cdot \mathrm{min}-1$. Oil under pressure is fed to the servomotor, which is able to carry out the pressing process in the chip pressing chamber at a pressure of up to $110.0 \mathrm{MPa}$, which is sufficient to obtain a durable briquette structure.

During the analysis of the test results, a regression analysis was performed to fit the points from the measurements of the straight line or $n$-th curve. Examples of regression results for individual studies and selected runs are presented in Table 2 to Table 4.

\section{Results and discussion}

In first step testing the influence of pressure on the density of briquettes for different types of wood were presented. $10 \mathrm{~mm}$ chips from three trees: pine, oak and hornbeam were used for the analysis. The test results are shown in Fig. 2.

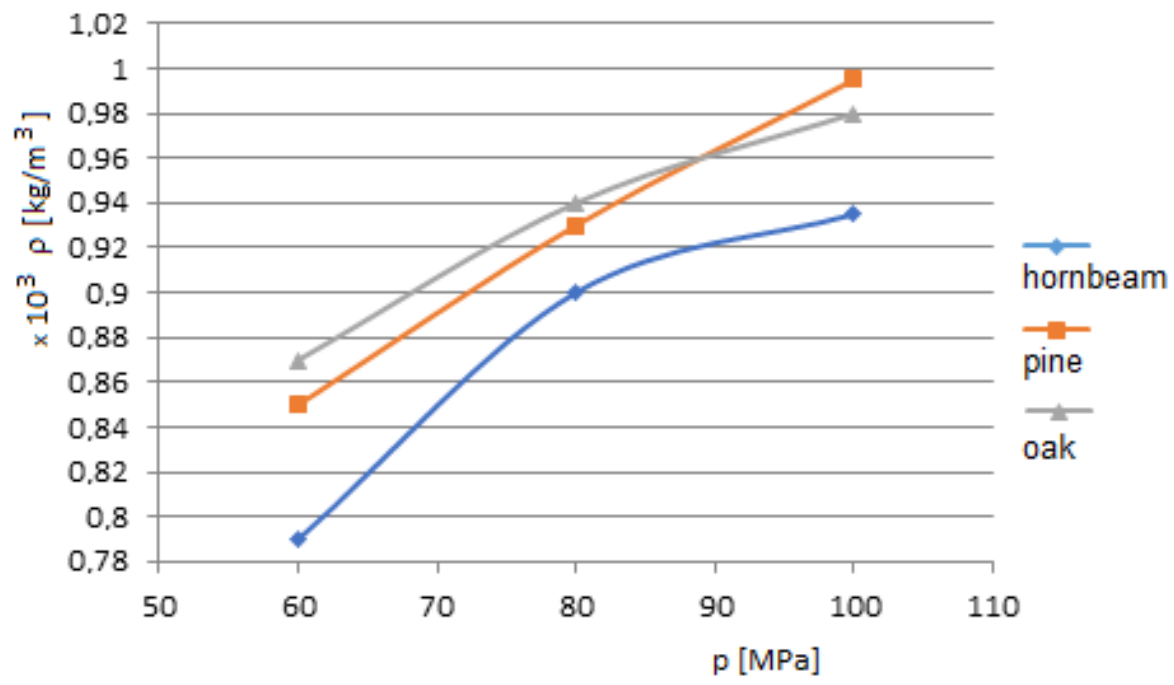

Fig. 2. Influence of pressure on the obtained briquette density for three types of biomass with a chip size of $10 \mathrm{~mm}$

Analysis of the obtained results showed that with the same size chip briquettes made of pine and oak have comparable densities. The sample made of hornbeam has a density lower by approximate $50 \mathrm{~kg} \cdot \mathrm{m}^{-1}$ at a maximum pressing pressure of $100 \mathrm{MPa}$. In addition, a straight relationship between the density and compression pressure is observed with a sample of pine chips. The results of the pooled regression test for the dependent variables are presented in Table 2.

Table 2

Summary of regression results of sample density vs forming pressure for pine chip size of

$10 \mathrm{~mm}: R=0.87284385, R 2=0.76185639$, corrected $R 2=0.75884191$, value of $t$-Student statistics $(\mathbf{1 . 7 9})=\mathbf{2 5 2 . 7 3}$

\begin{tabular}{|c|c|c|c|c|c|c|}
\hline Parameter & $\boldsymbol{\beta}$ & $\begin{array}{c}\text { Statistical } \\
\text { error }\end{array}$ & $\boldsymbol{B}$ & $\begin{array}{c}\text { Statistical } \\
\text { error }\end{array}$ & $\begin{array}{c}\boldsymbol{t} \text {-Student } \\
(\mathbf{1 . 7 9})\end{array}$ & $\boldsymbol{p}$-level \\
\hline Constant term & - & - & 0.643333 & 0.017120 & 37.57799 & 0.00001 \\
\hline Pressure & 0.872844 & 0.054904 & 0.003333 & 0.000210 & 15.89757 & 0.00001 \\
\hline
\end{tabular}

Further research concerns the dependence of the sample density on the raw material fraction. Pine chips with a fraction size of 5,10 and $15 \mathrm{~mm}$ were used. The results of this study are shown in Fig. 3 .

The analysis of the obtained results shows that at low pressing pressure $(60 \mathrm{MPa})$, with a decrease in the fractional size, higher density of the briquette is obtained. The difference between the 5 and 15 $\mathrm{mm}$ fraction is $50 \mathrm{~kg} \cdot \mathrm{m}^{-1}$. However, when the pressure increases to $100 \mathrm{MPa}$, the size of the fraction practically does not affect the density of the sample. In the initial compression period, the feed elements are moved, so that voids between them are eliminated. The increase in pressure at the end of the pressing process leads to transition from the elastic behaviour of the charge material to plastic deformation, as a result of which the briquette structure is hardened, and the shape is given. 


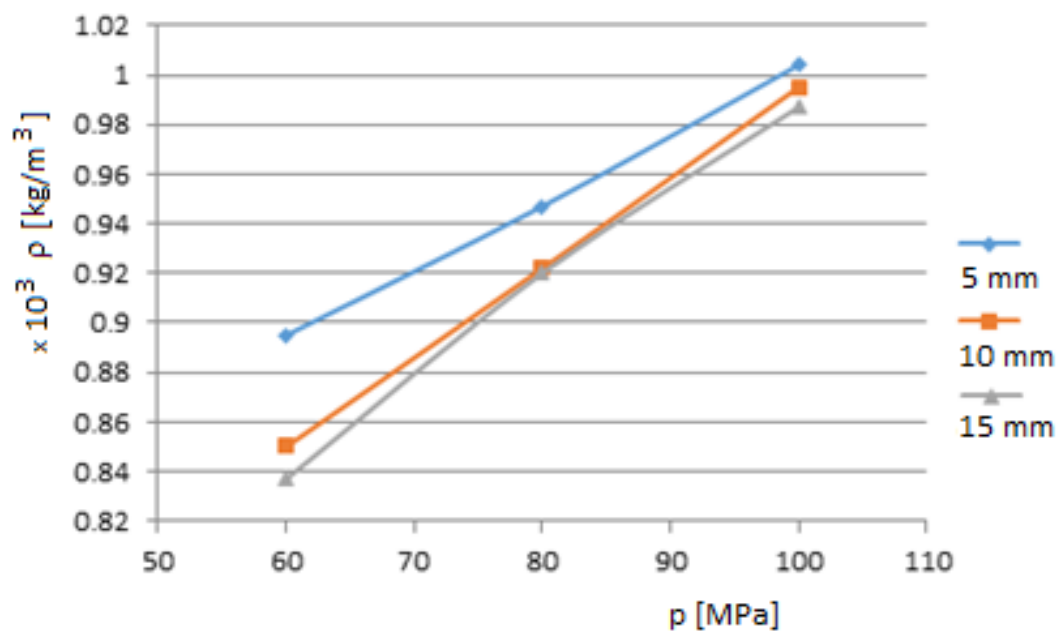

Fig. 3. Influence of pressure on the obtained briquette density of pine chips

Table 3

Summary of regression results of sample density vs forming pressure for pine chip size of

$15 \mathrm{~mm}: R=0.95480797, R 2=0.91165825$, corrected $R 2=0.91054000$,

value of $t$-Student statistics $(1.79)=815.25$

\begin{tabular}{|c|c|c|c|c|c|c|}
\hline Parameter & $\boldsymbol{\beta}$ & $\begin{array}{c}\text { Statistical } \\
\text { error }\end{array}$ & $\boldsymbol{B}$ & $\begin{array}{c}\text { Statistical } \\
\text { error }\end{array}$ & $\begin{array}{c}\boldsymbol{t} \text {-Student } \\
(\mathbf{1 . 7 9})\end{array}$ & $\boldsymbol{p}$-level \\
\hline Constant term & - & - & 0.659333 & 0.009627 & 68.48526 & 0.000001 \\
\hline Pressure & 0.954808 & 0.033440 & 0.003367 & 0.000118 & 28.55266 & 0.000001 \\
\hline
\end{tabular}

In the second step of the analysis testing on the influence of the number of pressing cycles on the density of the briquette were presented.

To ensure the reliability of the results obtained, one type of raw material was used in the study pine, $10 \mathrm{~mm}$ fraction. The study was conducted with the following process parameters:

- Single cycle - pressing the input material until maximum pressure is reached,

- Double cycle - pressing the input material until maximum pressure is reached, loosening, repressing at maximum pressure,

- Triple cycle.

The difference in the sample density for single and double cycles for each pressure value is $100 \mathrm{~kg} \cdot \mathrm{m}^{-1}$. The results of this testing are shown in Fig. 4.

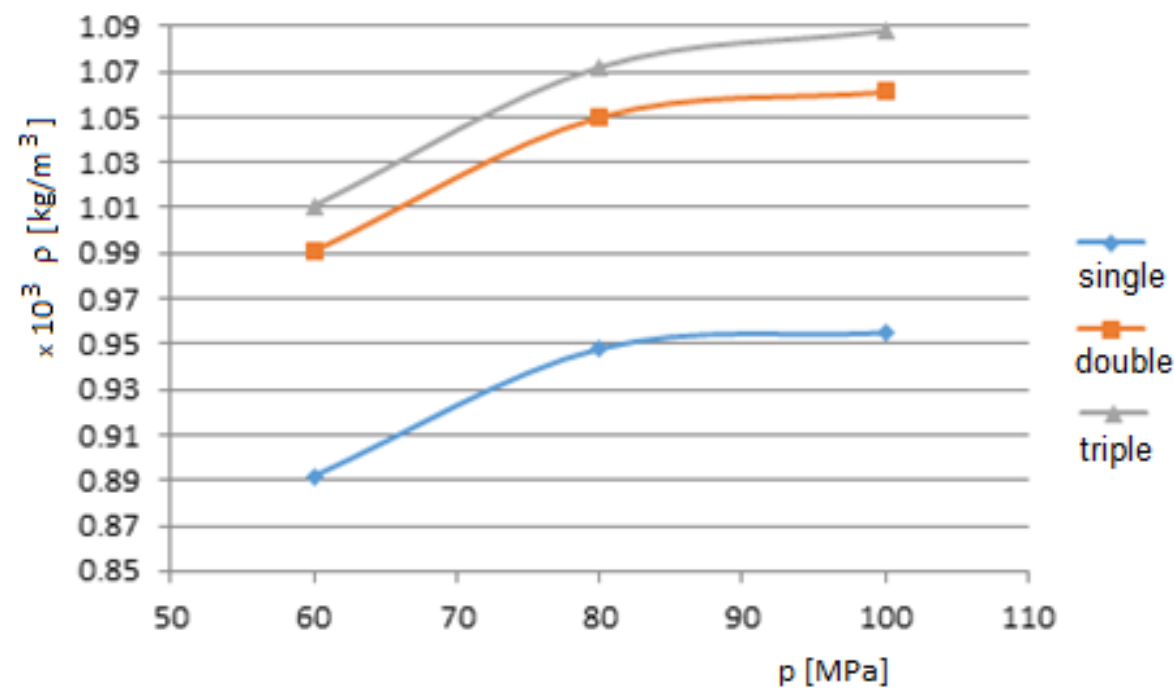

Fig. 4. Dependence of sample density on the number of compression cycles for $10 \mathbf{~ m m}$ pine chip 
Based on the analysis, we can see that the conditions of conducting tests depending on the pressing cycle affect the obtained values of the density of fuel briquettes. The use of a triple compression cycle does not significantly change the density compared to the double cycle, the density increases by approx. $20 \mathrm{~kg} \cdot \mathrm{m}^{-1}$. Pressing fuel briquettes with a double cycle leads to a significant improvement in the density of the samples obtained. However, the use of such a design solution for the pressing system should be proceeded by an energy analysis of the station and the associated economic analysis of briquette production.

Table 4

Summary of regression results of sample density vs forming pressure for pine chip size of 10 mm, double cycle: $R=0.45492357, R 2=0.20695546$, corrected $R 2=0.19691692$, value of $t$-Student statistics $(1.79)=\mathbf{2 0 . 6 1 6}$

\begin{tabular}{|c|c|c|c|c|c|c|}
\hline Parameter & $\boldsymbol{\beta}$ & $\begin{array}{c}\text { Statistical } \\
\text { error }\end{array}$ & $\boldsymbol{B}$ & $\begin{array}{c}\text { Statistical } \\
\text { error }\end{array}$ & $\begin{array}{c}\boldsymbol{t} \text {-Student } \\
\mathbf{( 1 . 7 9 )}\end{array}$ & $\boldsymbol{p}$-level \\
\hline Constant term & - & - & 0.867778 & 0.031469 & 27.57524 & 0.0000001 \\
\hline Pressure & 0.45492 & 0.100193 & 0.001750 & 0.000385 & 4.54049 & 0.000020 \\
\hline
\end{tabular}

Studies in the impact of the pressing cycle speed on the briquette density were carried out for one type of raw material. The tests were carried out while maintaining a constant pressing pressure $p=100 \mathrm{MPa}$ and pine chips with a size of $10 \mathrm{~mm}$. The results of this testing are shown in Fig. 5.

As it can be seen in Fig. 5, the pine chip cutting cycle should be carried out at the lowest possible pressing speed, because higher density of the briquette is obtained. Obtaining the highest density of briquette is associated with slow pressing of the chip, an increase in friction between chips and a higher pressing temperature. Many technological factors (size fraction, moisture content, and others) have major effects on the densification process of biomass to the form of high-grade solid biofuel [53]. It has been shown that the density of the input material does not affect the mechanical properties of the briquette: pine $-520 \mathrm{~kg} \cdot \mathrm{m}^{-1}$, hornbeam $-532 \mathrm{~kg} \cdot \mathrm{m}^{-1}$, oak $-710 \mathrm{~kg} \cdot \mathrm{m}^{-1}$. Conditions in the pressing chamber during densification can significantly impact the resulting briquettes quality [54]. Despite the advantages of pine briquettes, it should be remembered that the best fireplace briquettes are from deciduous trees. The briquette burns with an even flame. Pine briquettes due to the resin they contain during combustion pollute the hearth and chimney flues. In addition, the energy value of oak and hornbeam briquettes is $10.6 \mathrm{GJ} \cdot \mathrm{m}^{-1}$, while of pine it is $7.8 \mathrm{GJ} \cdot \mathrm{m}^{-1}$.

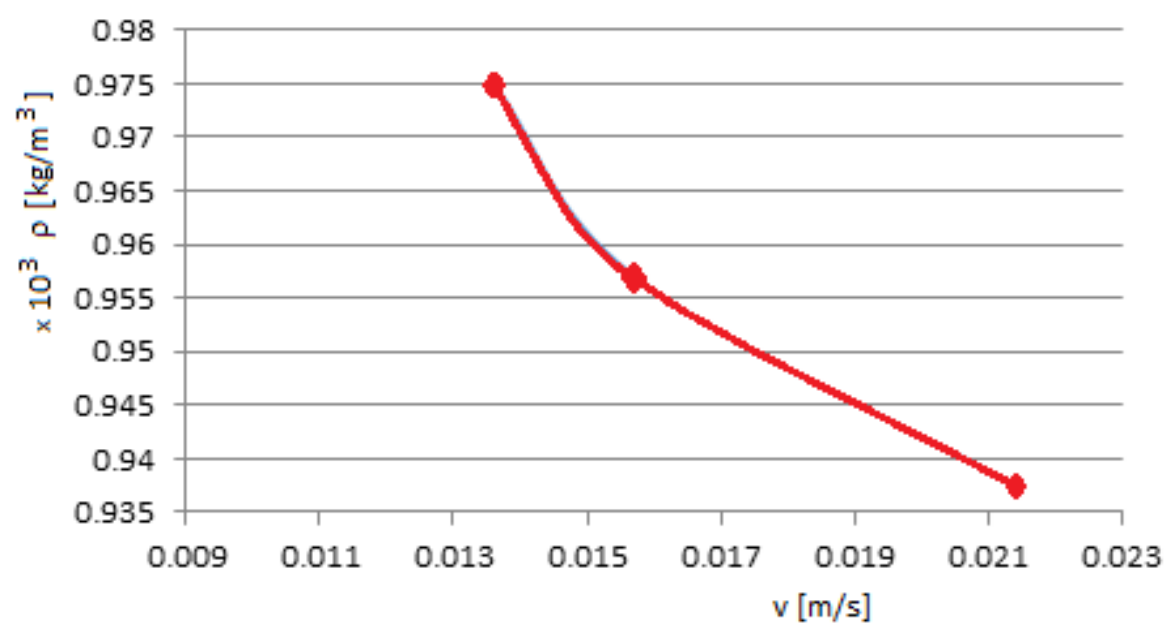

Fig. 5. Dependence of the sample density on the pressing speed for pine chips

When pressing one type of raw material at the same pressure, as the cycle speed increases, the density of the briquette decreases. During low pressing speed, more heat is released as a result of friction between the batch elements and the plastic deformation of wood chips is consolidated. As the research by Szmigielski et al. shows [26], the thickening of fuels increases their bulk density, which helps reduce the cost of product transport. The performed measurements and visualization of the results make it possible to determine the working conditions of the pressing device and the physical properties of the input material. 
Briquettes prepared from wood and municipal waste, which were characterized by a significant range of obtained calorific values, are also subject to testing $7.4 \div 18.2 \mathrm{MJ} \cdot \mathrm{kg}^{-1}$ [55]. The article shows that sewage sludge has a stabilizing effect on the durability of the pellets. Emissions of $\mathrm{NO}, \mathrm{NO}_{2}, \mathrm{NO}_{\mathrm{x}}$ and $\mathrm{H}_{2} \mathrm{~S}$ to the atmosphere from the combustion of pellets from waste biomass were lower than the emissions from the combustion of willow pellets $[31 ; 55]$. The briquetting process is a process of compressing the material under high pressure, with generation of heat caused by friction forces between pieces of compressed input material. As a result of this process, lignin is released, which is a binder for briquetting. Lignin is plasticized as a result of pressure, humidity and temperature in the range of about $75-120^{\circ} \mathrm{C}$. Therefore, when thickening biomass, one should strive to overcome its elasticity and plasticize lignin. This will permanently deform the compacted material particles and create new connections between them. In many works $[18 ; 21 ; 23 ; 38 ; 53 ; 55]$, the authors confirm the importance of testing technological parameters, such as the ironing pressure or temperature and pay attention to the density of solid fuel obtained from wood waste in the form of briquettes.

\section{Conclusions}

According to the research and literature studies, selected biomass materials can be effectively used as fuel for energy production and constitute one of the possibilities to stimulate and develop rural and forest areas.

Based on the conducted research, the following detailed conclusions can be formulated:

1. Comparable densities of pine and oak briquettes result from the low compressive strength of these wood species, respectively 47 and $52 \mathrm{MPa}$. Hornbeam with compressive strength of $66 \mathrm{MPa}$ gives briquettes with a lower density compared to pine and oak.

2. Based on the test results we can say that the best input material for the production of briquettes in terms of energy expenditure for the obtained density of briquettes are pine chips with a fraction size of $5 \mathrm{~mm}$.

3. The density of the pine briquette, directly affecting its durability, should be obtained in a double pressing cycle. Then the consolidation of the pressing process is observed by consolidating the plastic deformation of the chips.

4. The highest density of the briquette is then obtained due to slow compaction of the charge material, increase in friction between chips and increase in the pressing temperature.

\section{Acknowledgements}

This research was funded by KEGA grant number 033ŽU-4/2018 "Heat sources and pollution of the environment" APVV-15-0790 "Optimalization of biomass combustion with low ash melting temperature" and VEGA grant number 1/0233/19 "Construction modification of the burner for combustion of solid fuels in small heat sources".

\section{References}

[1] https://ungc.org.pl/sdg/sustainable-develompent-goals/( accessed on 10.07.2019).

[2] Borawski P., Beldycka-Borawska A., Szymańska E. Development of renewable energy sources market and biofuels in The European Union. Journal of Cleaner Production, vol. 228, 2019, pp. 467-484.

[3] Kumar P., Sharma H., Pal N., Kumar P. Comparative assessment and obstacles in the advancement of renewable energy in India and China. Problems of Sustainable Development, vol. 14, 2, 2019, pp. 191-200.

[4] Johansson T., Pirouzfar P. Sustainability challenges in energy use behaviour in households. Comparative Review of Selected Survey-based Publications from Developed and Developing Countries, Problems of Sustainable Development, vol. 14, 2, 2019, pp. 33-44.

[5] Morren M., Grinstein A. Explaining environmental behavior across borders: a meta-analysis. Journal of Environmental Psychology, vol. 47, 2016, pp. 91-106.

[6] Marczuk A., Misztal W., Szmigielski M., Zarajczyk J., Kowalczuk J., Jóźwiakowski K. Chemical consequences of inappropriate segregation of electrowaste. Przemysl Chemiczny, vol. 94, 10, 2015, pp. 1703-1707. 
[7] Veselík P., Sejkorová M., Nieoczym A., Jacek Caban J. Outlier Identification of Concentrations of Pollutants in Environmental Data Using Modern Statistical Methods. Pol. J. Environ. Stud., vol. 29, 1, 2020, pp. 853-860.

[8] Hunicz J., Mikulski M., Gęca M.S., Kordos P., Komsta H. Late direct fuel injection for reduced combustion rates in a gasoline controlled auto-ignition engine. Thermal Science, vol. 22, 3, 2018, pp. 1299-1309.

[9] Lebedevas S., Pukalskas S., Dauksys V., Rimkus A., Melaika M., Jonika L. Research on fuel efficiency and emissions of converted diesel engine with conventional fuel injection system for operation on Natural Gas. Energies, vol. 12, 2019, 2413.

[10] Rimkus A., Matijošius J., Bogdevicius M., Bereczky A., Torok A. An investigation of the efficiency of using $\mathrm{O} 2$ and $\mathrm{H} 2$ (hydrooxile gas - $\mathrm{HHO}$ ) gas additives in a CI engine operating on diesel fuel and biodiesel. Energy, vol. 152, 2018, pp. 640-651.

[11] Longwic R., Sander P., Nieoczym A., Lotko W., Krzysiak Z., Samociuk W., Bąkowski H. Effect of some properties of hydrocarbon fuels on self-ignition delay. Przemysl Chemiczny, vol. 96, 5, 2017, pp. 1123-1127.

[12] Gardyński L., Kałdonek J. Comparative study of selected lubricating properties of biofuels. Advances in Science and Technology-Research Journal, vol. 7, 20, 2013, pp. 75-79.

[13] Gardyński L., Kałdonek J. Research on lubrication properties of selected raw plant and animal materials. Transport, vol. 35, 2020, pp. 20-25.

[14] Orynycz O., Świć A. The effects of material's transport on various steps of production system on energetic efficiency of biodiesel production. Sustainability, vol. 10, 8, 2018, 2736.

[15] Osipowicz T., Abramek K.F., Barta D., Drozdziel P., Lisowski M. Analysis of possibilities to improve environmental operating parameters of modern compression - ignition engines. Advances in Science and Technology-Research Journal, vol. 12, 2, 2018, pp. 206-213.

[16] Chen W.H., Peng J., Bi X.T. A state-of-the-art review of biomass torrefaction, densification and applications. Renewable and Sustainable Energy Reviews, vol. 44, 2015, pp. 847-866.

[17] Krzyżaniak M., Stolarski M.J., Szczukowski S., Tworkowski J., Bieniek A., Mleczek M. Willow biomass obtained from different soils as a feedstock for energy. Industrial Crops and Products, vol. 75, part B, 2015, pp. 114-121.

[18] Orynycz O. Influence of tillage technology on the energy efficiency of a rapeseed plantation. 7th International Scientific Symposium on Engineering, Project and Production Management (EPPM). Procedia Engineering, 182, 2017, pp. 532-539.

[19] Matuš M., Križan P., Šooš L., Beniak J. The effect of papermaking sludge as an additive to biomass pellets on the final quality of the fuel. Fuel, vol. 219, 2018, pp. 196-204.

[20] Nosek R., Werle S., Borsukiewicz A., Zelazna A., Lagod G. Investigation of pellet properties produced from a mix of straw and paper sludge. Applied Sciences, vol. 10, 16, 2020, 5450.

[21] Fraga L., Teixeira J.C.F., Ferreira M.E.C. Technical review on biomass resource for wood pellets in Timor-Leste. In Proceedings of the 2018 3rd International Conference, Production of Scientific Knowledge in Timor-Leste, Dili, Timor-Leste, 12-14 September 2018, pp. 1-13.

[22] Guimarães C.D.S., Maia D.R.S., Serra E.G. Construction of biodigesters to optimize the production of biogas from anaerobic co-digestion of food waste and sewage. Energies, vol. 11, 2018, 870.

[23] Ivanova T., Mendoza H.A.H., Bradna, J., Fernández E., García M.J.C., Armas E.D.A. Assessment of guava (Psidium Guajava L.) wood biomass for briquettes' production. Forests, vol. 9, 2018, 613.

[24] Tucki K., Orynycz O., Wasiak A., Świć A., Wichlarz J. The impact of fuel type on the output parameters of a new biofuel burner. Energies, vol. 12,7, 2019, 1383.

[25] Wang L., Barta-Rajnai E., Skreiberg Ø., Khalil R., Czégény Z., Jakab E., Barta Z., Grønli M. Effect of torrefaction on physiochemical characteristics and grindability of stem wood, stump and bark. Applied Energy, vol. 227, 2018, pp. 137-148.

[26] Szmigielski M., Zarajczyk J., Węgrzyn A., Leszczyński N., Kowalczuk J., Andrejko D., Krzysiak Z., Samociuk W., Zarajczyk K. Testing the technological line for the production of alternative fuels. Przemysł Chemiczny, vol. 97, 7, 2018, pp. 1079-1082.

[27] Poudel J., Karki S., Oh S.C. Valorization of waste wood as a solid fuel by torrefaction. Energies, vol. $11,2018,1641$. 
[28] Słowik T., Szyszlak-Bargłowicz J., Zając G., Piekarski W. Limiting the environmental impact of road infrastructure through the use of roadside vegetation. Polish Journal of Environmental Study, vol. 24(4), 2015, pp. 1875-1879.

[29] Szyszlak-Bargłowicz J., Zając G., Kuranc A., Słowik T., Dudziak A., Stoma M., Wasilewski J. Chemical properties of selected agri-food industry waste products in the aspect of their use for energetics purposes. Przemysł Chemiczny, vol. 97,5, 2018, pp. 779-783.

[30] Monti A., Di Virgilio N., Venturi G. Mineral composition and ash content of six major energy crops. Biomass Bioenergy, vol. 32, 2008, pp. 216-223.

[31] Wróbel M., Mudryk K., Jewiarz M., Knapczyk A. Impact of raw material properties and agglomeration pressure on selected parameters of granulates obtained from willow and black locust biomass. $17^{\text {th }}$ International Scientific Conference Engineering for Rural Development, Jelgava, 23.25.05.2018, vol. 17, 2018, pp. 1933-1938.

[32] Szmigielski M., Zarajczyk J., Kowalczyk-Juśko A., Kowalczuk J., Rydzak L., Ślaska-Grzywna B., Krzysiak Z., Cycan D., Szczepanik M. Quality of biomass briquettes as stock for thermochemical conversion and syngas production. Przemysl Chemiczny, vol. 93, 11, 2014, pp. 1986-1990.

[33] Wasiak A., Orynycz O. Modelling of the dependence of energetic efficiency of biomass plantation upon energy fluxes going into subsidiary processes accompanying biomass production. Papers of the $23^{\text {rd }}$ European Biomass Conference: Setting the Course for a Biobased Economy, 2015, pp. 289293.

[34] Niemczuk B., Nieoczym A., Caban J., Marczuk A. Analysis of chemical and energy properties of energy willow in the industrial burning. Przemysl Chemiczny, vol. 97, 1, 2018, pp. 44-48.

[35] Szyszlak-Bargłowicz J., Zając G., Hawrot-Paw M., Koniuszy A. Evaluation of the quality of wood pellets available on the market. E3S Web of Conference, vol. 171, 2020, 01015.

[36]Zając G., Szyszlak-Bargłowicz J., Dudziak A., Kuranc A., Wasilewski J. Ash composition and deposition tendencies of selected biomass types. IX International Scientific Symposium Farm machinery and processes management in sustainable agriculture: Symposium Proceedings, edited by E. Lorencowicz, J. Uziak, B. Huyghebaert, 2017, pp. 438-443.

[37] Kraszkiewicz A., Kachel M., Parafiniuk S., Zając G., Niedziółka I., Sprawka M. Assessment of the possibility of using hemp biomass (Cannabis Sativa L.) for energy purposes: a case study. Applied Sciences, vol. 9,20, 2019, 4437.

[38] Križan P. Research of factors influencing the quality of wood briquettes. Acta Montanistica Slovaca, vol. 12, 3, 2007, pp. 223-230.

[39] Šooš L., Bábics J., Beniak J., Križan P., Kovač P., Matuš M. Design and testing functional model compacting machine for produce new shape biofuels. IOP conference Series: Materials Science and Engineering, vol. 501, 2018, 012008.

[40] Artemio C.P., Maginot N.H., Serafin C.U., Rahim F.P., Jose Guadelupe R.Q., Fermin C.M. Physical, mechanical and energy characterization of wood pellets obtained from three common tropical species. PEERJ2018, 6 Article Number: e 5504.

[41] Mendoza M.C.L, Sermyagina E., Carneiro A., Vakkilainen E. Production and characterization of coffee-pine wood residue briquettes as an alternative fuel for local firing systems in Brazil. Biomass \& Bioenergy, vol. 123, 2019, pp. 70-77.

[42] De Oliveira Vieira A.T., Do Nascimento A.M., De Andrade A.M., Junior A.F.D. Thermochemical properties of briquettes produced from charcoal fine and waste of Pinusspp wood. Scientia Forestalis/Forest Sciences, vol. 46, 119, 2018, pp. 483-493.

[43] Barwicki J., Marczuk A., Misztal W. Wood chips biomass storage problems and some experimental work concerning such existing processes. Fresenius Environmental Bulletin, vol. 29, 1, 2020, pp. 36-42.

[44] Boschetti W., Carvalho A., Carneiro A., Santos L.C., Poyares L. Potential of kraft lignin as an additive in briquette production. Nordic Pulp \& Paper Research Journal, vol. 34, 1, 2019, pp. 147152.

[45] Stolarski M.J., Krzyzaniak M., Warminski K. Energy consumption and costs of heating a detached house with wood briquettes in comparison to other fuels. Energy Conversion and Management, vol. 121, 2016, pp. 71-83. 
[46] Wihan J. Humidity in straw bale walls and its effect on the decomposition of straw. MSc. University of East London School, 2007, 44. Online: [06.12.2020] Available at: https://www.enertech.fr/pdf/45/humidite_murs_paille.pdf

[47] Trojanowski R., Fthenakis V. Nanoparticle emissions from residential wood combustion: A critical literature review, characterization, and recommendations. Renewable\&Sustainable Energy Reviews, vol. 103, 2019, pp. 515-528.

[48] Styks J., Wróbel M., Fraczek J., Knapczyk A. Effect of compaction pressure and moisture content on quality parameters of perennial biomass pellets. Energies, vol. 13,8, 2020, 1859.

[49] PN-EN ISO 17225-1:2014-07 Biopaliwa stałe -- Specyfikacje paliw i klasy -- Część 1: Wymagania ogólne.

[50] Tumuluru J.S., Wright C.T., Hess J.R., Kenney K.L. A review of biomass densification systems to develop uniform feedstock commodities for bioenergy application. Biofuels, Bioproducts and Biorefining, vol. 5, 2011, pp. 683-707.

[51] PN-EN ISO 17827-1 Biopaliwa stałe - Oznaczanie składu ziarnowego paliw niesprasowanych Część 1: Metoda przesiewania oscylacyjnego przy użyciu sit o wymiarach oczka 3,15 mm lub większych.

[52] PN-EN ISO 17827-2 Biopaliwa stałe -- Oznaczanie składu ziarnowego paliw niesprasowanych -Część 2: Metoda przesiewania wibracyjnego przy użyciu sit o wymiarach oczka 3,15 mm lub poniżej.

[53] Matuš M., Križan P., Šooš, L., Beniak J., Lisy M. The influence of size fraction and moisture content on the compressibility of wood sawdust in effective process of production a solid biofuel. 14th International Multidisciplinary Scientific GeoConference-SGEM. Albena, Bulgaria, JUN 1726, 2014, Geoconference on Energy and Clean Technologies, vol. 1 (SGEM 2014). 2014, pp. 553560.

[54] Križan P., Svatek M., Matuš M., Beniak J., Lisy M. Determination of compacting pressure and pressing temperature impact on biomass briquettes density and their mutual interactions. 14th International Multidisciplinary Scientific GeoConference-SGEM. Albena, Bulgaria, JUN 17-26, 2014, Geoconference On Energy And Clean Technologies, vol. 1 (SGEM 2014). 2014, pp. 133140.

[55] Greinert A., Mrówczyńska M., Szefner W. The use of waste biomass from the wood industry and municipal sources for energy production. Sustainability, vol. 11, 2019, 3083. 